\title{
Marinomonas basaltis sp. nov., a marine bacterium isolated from black sand
}

\author{
Ho-Won Chang, ${ }^{1}$ Seong Woon Roh, ${ }^{1,2}$ Kyoung-Ho Kim, ${ }^{1}$ \\ Young-Do Nam, ${ }^{1,2}$ Jung-Hoon Yoon, ${ }^{1}$ Hee-Mock Oh ${ }^{1}$ \\ and Jin-Woo Bae ${ }^{1,2,3}$ \\ ${ }^{1}$ Biological Resources Center, KRIBB, Daejeon 305-806, Republic of Korea \\ ${ }^{2}$ Korea University of Science and Technology, 52, Eoeun-dong, Daejeon 305-333, Republic of \\ Korea \\ ${ }^{3}$ Environmental Biotechnology National Core Research Center, Gyeongsang National University, \\ Jinju 660-701, Republic of Korea
}

Correspondence Jin-Woo Bae baejw@kribb.re.kr

\begin{abstract}
A Gram-negative, aerobic, slightly halophilic, rod-shaped bacterium was isolated from black sand in Soesoggak, Jeju island, Korea. The strain, designated $\mathrm{J} \mathrm{S}^{\top}$, was oxidase- and catalase-positive and arginine dihydrolase-negative. The isolate required $\mathrm{Na}^{+}$for growth and differed from phenotypically related species by being able to utilize sucrose and D-galactose as a carbon source. Phylogenetic analysis based on the sequence of the 16S rRNA gene revealed that strain $\mathrm{J} 3^{\top}$ belongs to the genus Marinomonas. It exhibited 16S rRNA gene sequence similarities of 97.6-98.7\% to the closely related species Marinomonas communis, Marinomonas ostreistagni, Marinomonas aquimarina and Marinomonas vaga. The phylogenetic analysis revealed that strain $\mathrm{J}_{63}{ }^{\top}$ comprised a relatively long subline of descent, shared a branch point with the outlying species Marinomonas communis and occupied a phylogenetically distant position on the main Marinomonas branch. Based on DNA-DNA hybridization, the levels of relatedness between strain $\mathrm{J} 3^{\top}$ and M. communis NBRC $102224^{\top}$, M. aquimarina CIP $108405^{\top}$ and M. vaga JCM $20774^{\top}$ were $56.2,45.1$ and $51.3 \%$, respectively. On the basis of the phenotypic, genetic and phylogenetic data, strain $\mathrm{J}_{6} 3^{\top}$ should be placed in the genus Marinomonas as representing a novel species, for which the name Marinomonas basaltis sp. nov. is proposed. The type strain is $\mathrm{J}_{63}{ }^{\top}\left(=\mathrm{KCTC} 22118^{\top}=\mathrm{JCM} 14948^{\top}\right)$.
\end{abstract}

The genus Marinomonas was created to accommodate two reclassified Alteromonas species, namely Alteromonas communis and Alteromonas vaga (Baumann et al., 1972). These species formed a separate and distinct branch when compared with other species of Alteromonas (Van Landschoot \& De Ley, 1983). At the time of writing, the genus Marinomonas comprised 10 species with validly published names (http://www.bacterio.cict.fr/m/marinomonas. html), which are phenotypically heterogeneous. Species assigned to the genus Marinomonas are rod-shaped and motile by polar or peritrichous flagella, have DNA G+C contents in the range $46.9-48.0 \mathrm{~mol} \%$ and the ability to metabolize $m$ hydroxybenzoate, $p$-hydroxybenzoate and quinate and to utilize acetate. The recognized species of the genus Marinomonas were M. aquimarina, M. communis, M. dokdonensis, M. mediterranea, M. ostreistagni, M. polaris, M. pontica, M. primoryensis, M. ushuaiensis and M. vaga (Baumann et al., 1972; Gupta et al., 2006; Ivanova et al., 2005; Lau et al., 2006;

The GenBank/EMBL/DDBJ accession number for the 16S rRNA gene sequence of strain $\mathrm{J}_{63}{ }^{\top}$ is EU143359.
Macian et al., 2005; Prabagaran et al., 2005; Romanenko et al., 2003; Solano \& Sanchez-Amat, 1999; Van Landschoot \& De Ley, 1983; Yoon et al., 2005). A Marinomonas-like, Gramnegative, rod-shaped bacterial strain, $\mathrm{J} 63^{\mathrm{T}}$, was isolated recently from black sand from Soesoggak, Jeju island, Korea, by using the dilution-plating technique. In this report, we describe the morphological, biochemical and phylogenetic characteristics of strain $\mathrm{J} 63^{\mathrm{T}}$.

Soesoggak is a coastal area, surrounded by basalt on three sides, in the south of Jeju island $\left(33^{\circ} 15^{\prime} 16^{\prime \prime} \mathrm{N} 126^{\circ} 37^{\prime}\right.$ $52^{\prime \prime}$ E). A seawater sample with black sand $(50 \mathrm{ml})$, collected in a sterile tube, was placed directly on $10 \%$ marine agar 2216 (MA; Difco). Several representative colonies appeared on $10 \%$ MA after incubation at $30{ }^{\circ} \mathrm{C}$ for 1 day. One of the representative colonies, designated strain $\mathrm{J} 63^{\mathrm{T}}$, was grown routinely at $30{ }^{\circ} \mathrm{C}$ for 3 days on MA or in marine broth (MB; Difco). Cell morphology was examined by using light microscopy (E600; Nikon) and transmission electron microscopy. Cellular motility of the novel isolate was observed in fresh wet-mounts of young 
bacterial cultures in $\mathrm{MB}$ by using the hanging drop method. The presence of flagella was investigated by transmission electron microscopy, with cells from an exponentially growing culture. The Gram-reaction was determined using a Gram Stain kit (Difco), according to the manufacturer's instructions. The reference strains used, M. communis NBRC $102224^{\mathrm{T}}$, M. aquimarina CIP $108405^{\mathrm{T}}$ and M. vaga JCM $20774^{\mathrm{T}}$, were the closest relatives based on 16S rRNA gene similarity. The strains were obtained from NBRC, CIP and JCM and were grown under the same conditions. Cultures of the isolate and the reference strains were stored at $-80{ }^{\circ} \mathrm{C}$ in $\mathrm{MB}$ containing $20 \%$ glycerol. For morphological and physiological characterization, strain $\mathrm{J} 63^{\mathrm{T}}$ was generally cultivated in $\mathrm{MB}$, incubated by shaking at $30{ }^{\circ} \mathrm{C}$. The requirement and tolerance of various $\mathrm{NaCl}$ concentrations $(0-10 \%$; in increments of $1 \%)$ were determined in broth medium that comprised all of the constituents of $\mathrm{MB}$ except $\mathrm{NaCl}$, supplemented with appropriate concentrations of $\mathrm{NaCl}$. Growth at various temperatures and $\mathrm{pH}$ values was determined using $\mathrm{MB}$. Growth under anaerobic conditions was determined after incubation for 7 days in anaerobic Gaspak jars (BBL) containing $80 \% \mathrm{~N}_{2}, 10 \% \mathrm{CO}_{2}$ and $10 \% \mathrm{H}_{2}$. Catalase activity was determined by bubble production in a $3 \%$ (v/v) $\mathrm{H}_{2} \mathrm{O}_{2}$ solution and oxidase activity by using an oxidase reagent (bioMérieux). API 20NE and API ZYM test strips (bioMérieux) with inoculating fluid $(0.85 \% \mathrm{NaCl})$ and Biolog GN metabolic fingerprinting plates with GN/ GP inoculating fluid were used to analyse the biochemical and physiological traits of the bacterial strains; additional biochemical tests were performed using methods and media described previously by Gordon et al. (1973). Gelatin and starch hydrolysis were investigated as described by Smibert \& Krieg (1994). Bacterial strains grown on MA for 3 days at $30{ }^{\circ} \mathrm{C}$ were used for the analysis of fatty acid methyl esters. The fatty acid methyl esters were extracted and prepared according to standard protocols provided by the MIDI/Hewlett Packard Microbial Identification System (Sasser, 1990). Chromosomal DNA was extracted and purified, according to the method of Sambrook et al. (1989). The 16S rRNA gene was amplified by PCR using PCR Master mix solution (iNtRON Biotechnology, Korea) and two universal primers, as described previously (Stackebrandt et al., 1993). Sequencing of the amplified $16 \mathrm{~S}$ rRNA gene and phylogenetic analysis were performed as described previously (Roh et al., 2008). The DNA G+C content was determined using real-time PCR, as described by Gonzalez \& Saiz-Jimenez (2002). DNA-DNA hybridization was performed fluorometrically according to the method of Ezaki et al. (1989), using photobiotin-labelled DNA probes and microwell plates. The $16 \mathrm{~S}$ rRNA gene sequence of strain $\mathrm{J} 3^{\mathrm{T}}$ was aligned with ten reference sequences from the RDP database (Fig. 1) using the multiple sequence alignment program CLUSTAL_X (1.8) (Thompson et al., 1997). Phylogenetic relationships between representatives of the genus Marinomonas were determined using MEGA version 2.1 software. Distance matrices were determined following the assumptions described by Kimura (1980). These matrices were used to elaborate dendrograms using the neighbour-joining (Saitou \& Nei, 1987) and maximum-parsimony (Kluge \& Farris, 1969) methods. A bootstrap analysis for investi-

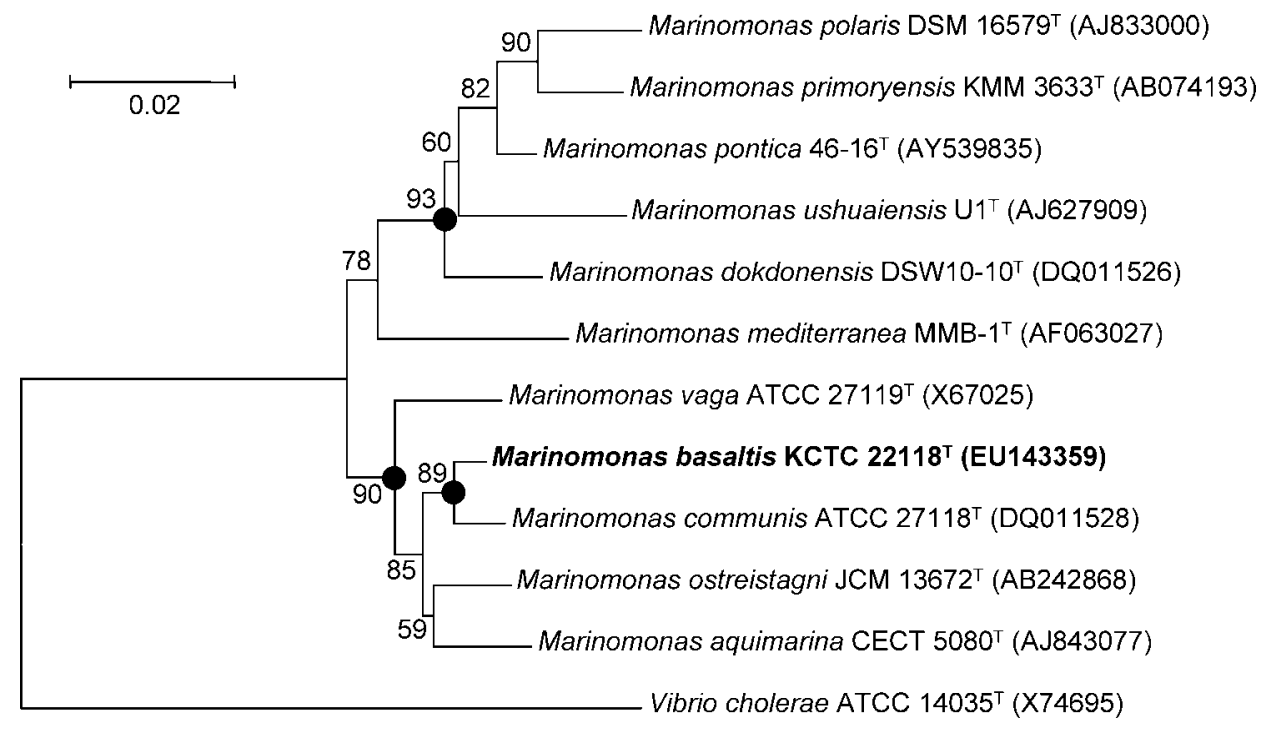

Fig. 1. Consensus phylogenetic tree based on $16 \mathrm{~S}$ rRNA gene sequences showing the relationship between strain $J 63^{\top}$ and type strains of recognized Marinomonas species.. The tree was constructed based on the neighbour-joining method and $p$ distances. Filled circles indicate generic branches that were also recovered by using the maximum-parsimony algorithm. Bootstrap analyses were performed with 1000 repetitions; only values $>50 \%$ are shown. GenBank accession numbers are given in parentheses. Bar, $0.02 \%$ sequence divergence. 
gating the stability of the trees was performed by obtaining a consensus tree based on 1000 randomly generated trees.

The morphological, cultural, physiological and biochemical characteristics of strain $\mathrm{J}_{6} 3^{\mathrm{T}}$ and other related species are shown in Table 1, and are described below. Cells of strain J63 ${ }^{\mathrm{T}}$ were Gram-negative, motile, slightly halophilic and rod-shaped, grew at temperatures of $10-45{ }^{\circ} \mathrm{C}$, but not below $10{ }^{\circ} \mathrm{C}$ or above $45{ }^{\circ} \mathrm{C}$, and at $\mathrm{pH} 5-10$, but not at $\mathrm{pH}$ values below 5 or above 10. Growth occurred in the presence of $1-7 \% \mathrm{NaCl}$; very weak growth occurred at $1-$ $2 \% \mathrm{NaCl}$. No growth was detected in less than $1 \%$ or more than $7 \% \mathrm{NaCl}$. The isolate did not grow under anaerobic conditions, and showed catalase and oxidase activities. The fatty acid methyl esters of strain $\mathrm{J} 63^{\mathrm{T}}$ and closely related species are shown in Table 2 . The fatty acid composition of strain $\mathrm{J} 3^{\mathrm{T}}$ exhibited a similar trend to those of members of the genus Marinomonas and was similar to those of the reference strains. However, strain $\mathrm{J} 63^{\mathrm{T}}$ had a slightly higher percentage of hydroxy fatty acids than $M$. communis and $M$. aquimarina and a lower percentage of unsaturated fatty acids compared with the other reference strains. Strain J63 differed from $M$. communis and $M$. vaga in having a higher percentage of straight-chain fatty acids.

Phylogenetic analysis based on the sequences of the $16 \mathrm{~S}$ rRNA genes of members of different genera of
Oceanospirillaceae that included Marinomonas species revealed that strain $\mathrm{J} 63^{\mathrm{T}}$ fell within a cluster comprised of Marinomonas species (Fig. 1). Strain $\mathrm{J}^{6}{ }^{\mathrm{T}}$ was $93.6-98.7 \%$ similar in its $16 \mathrm{~S}$ rRNA gene sequence to strains of other recognized Marinomonas species. On the basis of the $16 \mathrm{~S}$ rRNA gene sequence, strain $\mathrm{J} 63^{\mathrm{T}}$ was closely related to $M$. communis, M. ostreistagni, $M$. aquimarina and $M$. vaga with 98.7, 98.4, 97.8 and $97.6 \%$ similarity, respectively. DNADNA hybridization studies were performed to determine the genetic relationships among strain $\mathrm{J} 63^{\mathrm{T}}$ and $M$. communis NBRC $102224^{\mathrm{T}}$, M. aquimarina CIP $108405^{\mathrm{T}}$ and $M$. vaga JCM $20774^{\mathrm{T}}$, its closest relatives in terms of $16 \mathrm{~S}$ rRNA gene similarity. The DNA-DNA hybridization values between strain $\mathrm{J} 63^{\mathrm{T}}$, M. communis NBRC $102224^{\mathrm{T}}$, M. aquimarina CIP $108405^{\mathrm{T}}$ and $M$. vaga JCM $20774^{\mathrm{T}}$ were $56.2,45.1$ and $51.3 \%$, respectively. Taken together, the phylogenetic and DNA-DNA hybridization results suggest that strain $\mathrm{J}_{63}{ }^{\mathrm{T}}$ represents a novel species of the genus Marinomonas, for which the name Marinomonas basaltis sp. nov. is proposed.

\section{Description of Marinomonas basaltis sp. nov.}

Marinomonas basaltis (ba.sal'tis. L. masc. gen. n. basaltis of basalt, pertaining to the source of isolation).

Cells are Gram-negative, aerobic and rod-shaped, with overall dimensions of $0.5-0.6 \mu \mathrm{m}$ (width) by $1.0-2.5 \mu \mathrm{m}$

Table 1. Taxonomic characteristics of strain $\mathrm{J} 63^{\top}$ and the type strains of related species of the genus Marinomonas

Strains: 1, strain J63 ${ }^{\mathrm{T}}$ (Marinomonas basaltis sp. nov.); 2, M. communis NBRC 102224 ${ }^{\mathrm{T}}$ (data from Baumann et al., 1972); 3, M. ostreistagni JCM $13672^{\mathrm{T}}$ (Lau et al., 2006); 4, M. aquimarina CIP $108405^{\mathrm{T}}$ (Macian et al., 2005); 5, M. vaga JCM 20774 ${ }^{\mathrm{T}}$ (Baumann et al., 1972); 6, M. pontica 46-16 ${ }^{\mathrm{T}}$ (Ivanova et al., 2005). All strains do not reduce nitrate to nitrite and are able to utilize L-alanine as a carbon source. +, Positive; -, negative; ND, data not available; $v$, variable; $\mathrm{w}$, weakly positive.

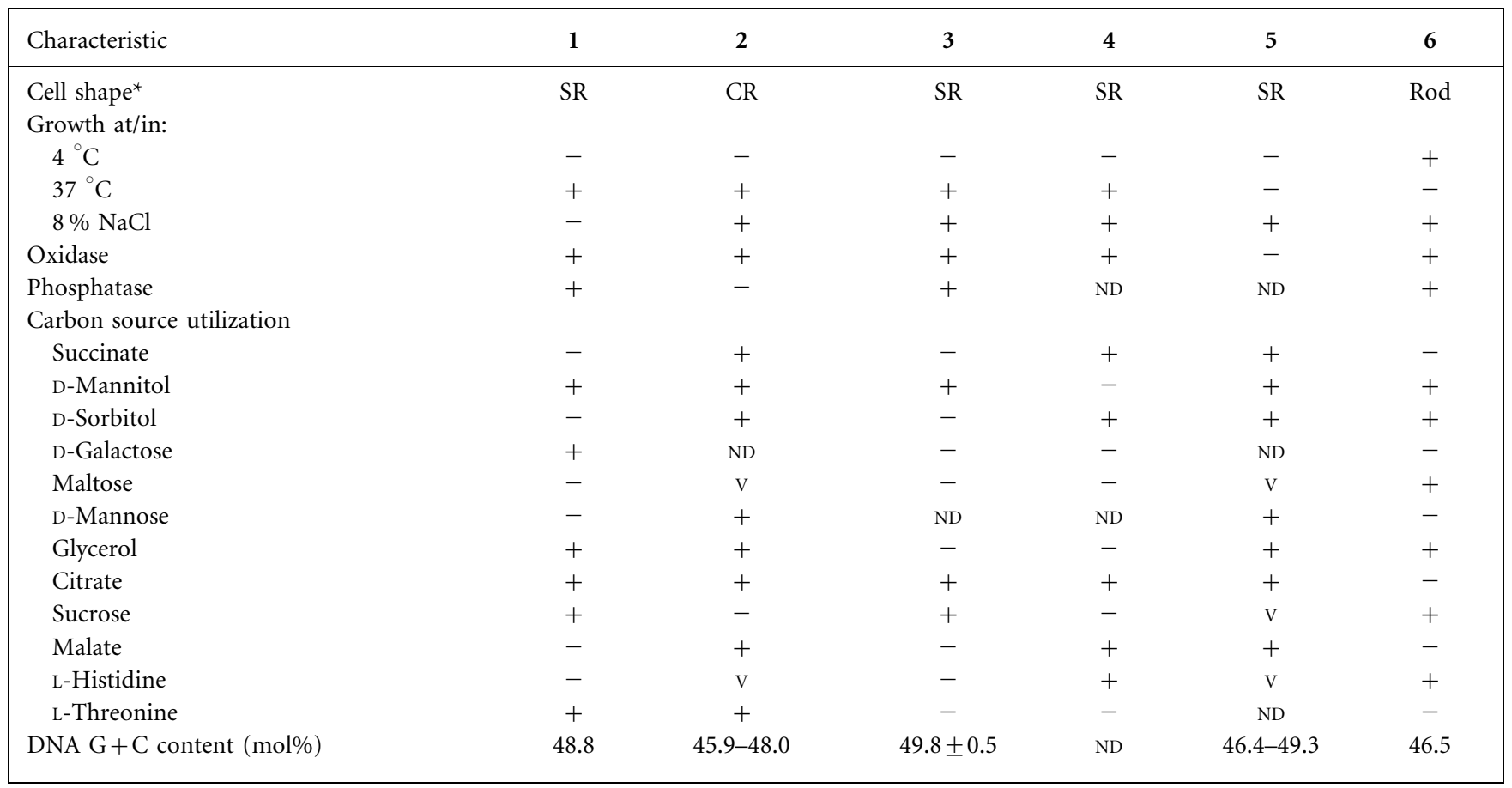

${ }^{\star} \mathrm{CR}$, Curved rod; SR, straight rod. 
Table 2. Fatty acid content (\%) of strain $\mathrm{J}_{6} 3^{\top}$ and related species of the genus Marinomonas

Strains: 1, strain $\mathrm{J}^{6} 3^{\mathrm{T}}$ (Marinomonas basaltis sp. nov.); 2, M. communis NBRC $102224^{\mathrm{T}}$; 3, M. aquimarina CIP $108405^{\mathrm{T}}$; 4, M. vaga JCM $20774^{\mathrm{T}}$. Values are percentages of total fatty acids. ECL, Equivalent chain-length. -, Not detected.

\begin{tabular}{|lrrrr|}
\hline Fatty acid & $\mathbf{1}$ & $\mathbf{2}$ & $\mathbf{3}$ & $\mathbf{4}$ \\
\hline Straight-chain fatty acids & & & & \\
$\quad 10: 0$ & 2.3 & 1.4 & 3.9 & 2.5 \\
$12: 0$ & 5.5 & 5.1 & 4.5 & 2.6 \\
$14: 0$ & 2.8 & 2.1 & 2.8 & 2.6 \\
$16: 0$ & 14.5 & 10.4 & 14.9 & 14.7 \\
$18: 0$ & 1.8 & 3.5 & 2.2 & 2.7 \\
Unsaturated fatty acids & & & & \\
$15: 1 \omega 8 c$ & 0.7 & 0.6 & 0.3 & - \\
$18: 1 \omega 7 c$ & 42.1 & 51.8 & 46.9 & 47.1 \\
Hydroxy fatty acids & & & & \\
$10: 03-$ OH & 7.6 & 7.6 & 5.7 & 8.9 \\
$12: 0$ 3-OH & 0.4 & 0.4 & 0.4 & - \\
$16: 0$ 3-OH & 0.4 & - & - & - \\
Summed feature & & & & \\
$16: 1 \omega 7 c / 15: 0$ iso 2-OH & 20.7 & 16.7 & 18.2 & 17.5 \\
Unknown ECL 11.7999 & 0.3 & 0.4 & 0.2 & 1.4 \\
& & & & \\
\hline
\end{tabular}

(length), as assessed in 3 day cultures grown at $30{ }^{\circ} \mathrm{C}$ on MA plates. Cells are motile by monopolar flagella. Colonies are circular to slightly irregular, opaque, smooth, lowconvex, ivory-coloured and $1-3 \mathrm{~mm}$ in diameter after incubation for 3 days on MA. Growth occurs in the presence of $1-7 \% \mathrm{NaCl}$, but not below $1 \%$ or above $7 \%$ $\mathrm{NaCl}$. Growth occurs at $10-45^{\circ} \mathrm{C}$ and within the $\mathrm{pH}$ range 5-10. No growth is detected below $\mathrm{pH} 5$ or above $\mathrm{pH} 10$. Growth does not occur in an anaerobic chamber on MA. Catalase- and oxidase-positive and arginine dihydrolasenegative. Gelatin and starch are not hydrolysed. According to API 20NE, indole production is negative. The following substrates are utilized as sole carbon and energy sources: Dmannitol, D-galactose, glycerol, citrate, sucrose, L-alanine, L-threonine, $\alpha$-cyclodextrin, $N$-acetyl-D-glucosamine, adonitol, L-arabinose, D-fructose, $\alpha$-D-glucose, myo-inositol, trehalose, turanose, pyruvic acid methyl ester, citric acid, D-gluconic acid, DL-lactic acid, succinic acid, L-asparagine, L-aspartic acid, L-glutamic acid, L-proline and L-pyroglutamic acid, but not succinate, D-sorbitol, cellobiose, maltose, D-mannose, malate, L-histidine, dextrin, glycogen, Tween 40, Tween 80, L-erythritol, L-fucose, gentiobiose, lactulose, melibiose, L-rhamnose, xylitol, acetic acid, formic acid, D-glucuronic acid and propionic acid. Using the API ZYM system, exhibits alkaline phosphatase, leucine arylamidase, valine arylamidase, trypsin, acid phosphatase, $\alpha$ glucosidase, $\beta$-glucosidase and $N$-acetyl- $\beta$-glucosaminidase activities. Does not exhibit esterase (C4), esterase lipase (C8), lipase (C14), cysteine arylamidase, $\alpha$-chymotrypsin, naphthol-AS-BI-phosphohydrolase, $\alpha$-galactosidase, $\beta$ galactosidase, $\beta$-glucuronidase, $\alpha$-mannosidase or $\alpha$-fuco- sidase activity. Predominant fatty acids are $18: 1 \omega 7 c$, $16: 1 \omega 7 c / 15: 0$ iso $2-\mathrm{OH}$ and $16: 0$. The DNA G+C content of the type strain is $48.8 \mathrm{~mol} \%$.

The type strain, $\mathrm{J}^{\mathrm{T}}{ }^{\mathrm{T}}\left(=\mathrm{KCTC} 22118^{\mathrm{T}}=\mathrm{JCM} 14948^{\mathrm{T}}\right.$ ), was isolated from black sand in Soesoggak, Jeju island, Korea.

\section{Acknowledgements}

This work was supported by the KRIBB Research Initiative Program (BDM0200726) and the Environmental Biotechnology National Core Research Center (KOSEF: R15-2003-012-02002-0) from the Ministry of Education, Science and Technology (MEST) of the Republic of Korea. The first author was supported by the Korea Research Foundation Grant funded by the Korean Government (MOEHRD, Basic Research Promotion Fund) (KRF-2007-512-C00016).

\section{References}

Baumann, L., Baumann, P., Mandel, M. \& Allen, R. D. (1972). Taxonomy of aerobic marine eubacteria. J Bacteriol 110, 402-429.

Ezaki, T., Hashimoto, Y. \& Yabuuchi, E. (1989). Fluorometric deoxyribonucleic acid-deoxyribonucleic acid hybridization in microdilution wells as an alternative to membrane filter hybridization in which radioisotopes are used to determine genetic relatedness among bacterial strains. Int J Syst Bacteriol 39, 224-229.

Gonzalez, J. M. \& Saiz-Jimenez, C. (2002). A fluorimetric method for the estimation of $\mathrm{G}+\mathrm{C}$ mol\% content in microorganisms by thermal denaturation temperature. Environ Microbiol 4, 770-773.

Gordon, R. E., Haynes, W. C. \& Pang, C. H.-N. (1973). The Genus Bacillus. US Department of Agriculture Handbook no. 427. Washington, DC: Agricultural Research Service.

Gupta, P., Chaturvedi, P., Pradhan, S., Delille, D. \& Shivaji, S. (2006). Marinomonas polaris sp. nov., a psychrohalotolerant strain isolated from coastal sea water of the subantarctic Kerguelen islands. Int J Syst Evol Microbiol 56, 361-364.

Ivanova, E. P., Onyshchenko, O. M., Christen, R., Lysenko, A. M., Zhukova, N. V., Shevchenko, L. S. \& Kiprianova, E. A. (2005). Marinomonas pontica sp. nov., isolated from the Black Sea. Int J Syst Evol Microbiol 55, 275-279.

Kimura, M. (1980). A simple method for estimating evolutionary rates of base substitutions through comparative studies of nucleotide sequences. J Mol Evol 16, 111-120.

Kluge, A. G. \& Farris, F. S. (1969). Quantitative phyletics and the evolution of anurans. Syst Zool 18, 1-32.

Lau, K. W., Ren, J., Wai, N. L., Lau, S. C., Qian, P. Y., Wong, P. K. \& Wu, M. (2006). Marinomonas ostreistagni sp. nov., isolated from a pearl-oyster culture pond in Sanya, Hainan Province, China. Int J Syst Evol Microbiol 56, 2271-2275.

Macian, M. C., Arahal, D. R., Garay, E. \& Pujalte, M. J. (2005). Marinomonas aquamarina sp. nov., isolated from oysters and seawater. Syst Appl Microbiol 28, 145-150.

Prabagaran, S. R., Suresh, K., Manorama, R., Delille, D. \& Shivaji, S. (2005). Marinomonas ushuaiensis sp. nov., isolated from coastal sea water in Ushuaia, Argentina, sub-Antarctica. Int J Syst Evol Microbiol 55, 309-313.

Roh, S. W., Sung, Y., Nam, Y. D., Chang, H. W., Kim, K. H., Yoon, J. H., Jeon, C. O., Oh, H. M. \& Bae, J. W. (2008). Arthrobacter soli sp. nov., a novel bacterium isolated from wastewater reservoir sediment. J Microbiol 46, 40-44. 
Romanenko, L. A., Uchino, M., Mikhailov, V. V., Zhukova, N. V. \& Uchimura, T. (2003). Marinomonas primoryensis sp. nov., a novel psychrophile isolated from coastal sea-ice in the Sea of Japan. Int $J$ Syst Evol Microbiol 53, 829-832.

Saitou, N. \& Nei, M. (1987). The neighbor-joining method: a new method for reconstructing phylogenetic trees. Mol Biol Evol 4, 406425.

Sambrook, J., Fritsch, E. F. \& Maniatis, T. (1989). Molecular Cloning: a Laboratory Manual, 2nd edn. Cold Spring Harbor, NY: Cold Spring Harbor Laboratory.

Sasser, M. (1990). Identification of bacteria by gas chromatography of cellular fatty acids, MIDI Technical Note 101. Newark, DE: MIDI Inc.

Smibert, R. M. \& Krieg, N. R. (1994). Phenotypic characterization. In Methods for General and Molecular Bacteriology, pp. 607-654. Edited by P. Gerhardt, R. G. E. Murray, W. A. Wood \& N. R. Krieg. Washington, DC: American Society for Microbiology.
Solano, F. \& Sanchez-Amat, A. (1999). Studies on the phylogenetic relationships of melanogenic marine bacteria: proposal of Marinomonas mediterranea sp. nov. Int J Syst Bacteriol 49, 1241-1246.

Stackebrandt, E., Liesack, W. \& Goebel, B. M. (1993). Bacterial diversity in a soil sample from a subtropical Australian environment as determined by $16 \mathrm{~S}$ rDNA analysis. FASEB J 7, 232-236.

Thompson, J. D., Gibson, T. J., Plewniak, F., Jeanmougin, F. \& Higgins, D. G. (1997). The CLUSTAL_X windows interface: flexible strategies for multiple sequence alignment aided by quality analysis tools. Nucleic Acids Res 25, 4876-4882.

Van Landschoot, A. \& De Ley, J. (1983). Intra- and intergeneric similarities of the rRNA cistrons of Alteromonas, Marinomonas (gen. nov.) and some other Gram-negative bacteria. J Gen Microbiol 129, 3057-3074.

Yoon, J. H., Kang, S. J. \& Oh, T. K. (2005). Marinomonas dokdonensis sp. nov., isolated from sea water. Int J Syst Evol Microbiol 55, 2303-2307. 